\title{
Competitive sorption of cadmium and lead in acid soils of Central Spain
}

Serrano, S. ${ }^{1}$, Garrido, F. ${ }^{*}$, Campbell, C. G. ${ }^{2}$ and García-González, M. T. ${ }^{1}$

${ }^{1}$ Centro de Ciencias Medioambientales, Consejo Superior de Investigaciones

Científicas. Serrano 115 dup. 28006 - Madrid (Spain).

${ }^{2}$ Earth Science Division, Lawrence Berkeley National Laboratory. 1 Cyclotron Rd, MS

90-1116, Berkeley, CA 94720 (USA)

* Corresponding author: fernando.garrido@ccma.csic.es 


\section{Summary}

The bioavailability and ultimate fate of heavy metals in the environment are controlled by chemical sorption. To assess competitive sorption of $\mathrm{Pb}$ and $\mathrm{Cd}$, batch equilibrium experiments (generating sorption isotherms) and kinetics sorption studies were performed using single and binary metal solutions in surface samples of four soils from central Spain. For comparisons between soils, as well as, single and binary metal solutions, soil chemical processes were characterized using the Langmuir equation, ionic strength, and an empirical power function for kinetic sorption. In addition, soil $\mathrm{pH}$ and clay mineralogy were used to explain observed sorption processes. Sorption isotherms were well described by the Langmuir equation and the sorption kinetics were well described by an empirical power function within the reaction times in this study. Soils with higher $\mathrm{pH}$ and clay content (characterized by having smectite) had the greatest sorption capacity as estimated by the maximum sorption parameter $(Q)$ of the Langmuir equation. All soils exhibited greater sorption capacity for $\mathrm{Pb}$ than $\mathrm{Cd}$ and the presence of both metals reduced the tendency for either to be sorbed although $\mathrm{Cd}$ sorption was affected to a greater extent than that of $\mathrm{Pb}$. The Langmuir binding strength parameter $(k)$ was always greater for $\mathrm{Pb}$ than for $\mathrm{Cd}$. However, these $k$ values tended to increase as a result of the simultaneous presence of both metals, that may indicate competition for sorption sites promoting the retention of both metals on more specific sorption sites. The kinetic experiments showed that $\mathrm{Pb}$ sorption is initially faster than Cd sorption from both single and binary solutions although the simultaneous presence of both metals affected the sorption of $\mathrm{Cd}$ at short times while only a minor effect was observed on $\mathrm{Pb}$. The estimated exponents of the kinetic function were in all cases smaller for $\mathrm{Pb}$ than for $\mathrm{Cd}$, likely due to diffusion processes into micropores or interlayer space of the clay minerals which occurs more readily for $\mathrm{Cd}$ than $\mathrm{Pb}$. Finally, the overall sorption processes of $\mathrm{Pb}$ and $\mathrm{Cd}$ in the smectitic soil with the highest 
sorption capacity of the studied soils are slower than in the rest of the soils with a clay mineralogy dominated by kaolinite and illite, exhibiting these soils similar sorption rates. These results demonstrate a significant interaction between $\mathrm{Pb}$ and $\mathrm{Cd}$ sorption when both metals are present that depends on important soil properties such as the clay mineralogy.

\section{Keywords:}

Lead; Cadmium; Sorption isotherms; Sorption kinetics; Competitive sorption; Acid soils. 


\section{Introduction}

Metals are natural constituents of soils. However, in the last decades, significant changes in the global budget of heavy metals at the earth's surface have occurred (Förstner, 1995). Industrial activities, fertilizer and sewage sludge applications as well as effluent disposal on land can result in significant input of heavy metals. This can lead to either substantial accumulation, in excess of the natural background, or leaching, potentially polluting surface or subsurface water bodies, or both.

Two of the most potentially toxic heavy metals are cadmium and lead. Classified as soluble and strongly hydrating cations (McBride, 1994), both metals are particularly toxic to higher animals, producing kidney and blood diseases among other health disorders. The term 'sorption' is used to describe the removal of metals in solution by the soil solid phase (Hooda and Alloway, 1994; Chen et al., 1997) including any retention mechanism that controls availability and mobility. Many studies have focused on the sorption of these metals on different soil materials and under different experimental conditions (Hooda and Alloway, 1998; Martínez and McBride, 1998; Sauvé et al., 2000; Appel and Ma, 2002; Krishnamurti and Naidu, 2003; Trivedi et al., 2003; Adhikari and Singh, 2003). Soil pH, other factors such as the presence of competing ligands, the ionic strength of the soil solution, and the simultaneous presence of competing metals are known to significantly affect sorption processes and leaching potential through a soil profile (Kookama and Naidu, 1998; Harter and Naidu, 2001).

However, despite the established significance of competitive sorption, and that sorption selectivity for a particular metal might result from its relative affinity for specific sites or its sorption on to sites unavailable to other metals (Benjamin and Leckie, 1981b), most soil-metal bonding information has been derived from studies conducted using single metal solutions. Also, while monoion sorption studies may 
adequately predict sorption of strongly bonded ions, sorption of less strongly bonded ions is more likely to be affected by the presence of competing ions in solution (Harter, 1992). Such studies may have limited practical applications when used to explain sorption in soils containing competitive cations (Fontes et al., 2000). Greater progress has been made in studying competitive sorption reactions in pure minerals and organic compounds (Kinniburgh et al., 1976; Tiller et al., 1979; Benjamin and Leckie, 1981b; Elliott et al., 1986; Bereket et al., 1997; Pinheiro et al., 1999; Saha et al., 2002) than in more heterogeneous soil surfaces (Cavallaro and McBride, 1978; Murali and Aylmore, 1983; Harter, 1992; Mesquita and Viera e Silva, 2002). However, theoretical sorption models based on simple mineral or organic systems appear unlikely to provide the means for quantitative predictions in complex soils (Tiller et al., 1984). Metal characteristics such as the charge-to-radius ratio (Gomes et al., 2001) or metal-ion hydrolysis constants (Welp and Brümmer, 1999) sequences do not always explain metal bonding selectivity to heterogeneous soil systems.

Therefore, we designed an investigation to examine the effect of the simultaneous presence of $\mathrm{Pb}$ and $\mathrm{Cd}$ on sorption behavior to acidic $\mathrm{A}$ horizons of temperate soils from Spain. Specifically, we have undertaken batch equilibrium experiments to generate sorption isotherms and kinetic sorption studies using single and binary metal solutions in four soils characterized with different proportions of variableand permanent-charge clay minerals. Results were characterized and compared for different metal solutions and soils using the Langmuir equation, ionic strength, the total metal retained in the soils, soils characteristics (including $\mathrm{pH}$ and clay content), and an empirical power function for kinetic sorption. 


\section{Materials and Methods}

\subsection{Soils}

We collected bulk samples of the topsoils $(0-15 \mathrm{~cm}$ depths $)$ from four acidic soils. Three soils (S1, S2, and S3) were developed from Pliocene-Quaternary aged formations (raña) in Cáceres, Spain. They were classified as a Plinthic Palexerult (S1), Ultic Palexeralf (S2), and Arenic Pachic Palexerult (S3) (Soil Survey Staff, 1999). The fourth soil was developed on a hillslope in Madrid (Spain) and was classified as a Vertic Haploxerert (S4). To obtain a homogeneous sample of the top soils at each location, three approximately 3-kg samples from $2 \mathrm{~m}$ apart of the same horizon of each soil were combined prior to the experiments. All samples were air-dried, crushed and sieved through a 2-mm mesh prior to soil characterization and sorption studies.

\subsection{General soil analyses}

Soil $\mathrm{pH}$ was measured in deionized water $\left(\mathrm{pH}_{\mathrm{w}}\right)$ and in $1 \mathrm{M} \mathrm{KCl}\left(\mathrm{pH}_{\mathrm{K}}\right)$ (in a 1:2.5 suspension), and organic carbon (OC) was determined by wet digestion (Walkley and Black, 1934). The exchangeable bases were extracted with $1 \mathrm{M} \mathrm{NH}_{4} \mathrm{OAc}(\mathrm{pH} 7)$ (Thomas, 1982), and the exchangeable aluminum $\left(\mathrm{Al}_{\mathrm{K}}\right)$ was extracted with $1 \mathrm{M} \mathrm{KCl}$ (Barnhisel and Bertsch, 1982). The effective capacity of the exchange complex (ECEC) was calculated as the sum of $\mathrm{Al}_{\mathrm{K}}$ and the amounts of $\mathrm{Ca}, \mathrm{Mg}, \mathrm{Na}$ and $\mathrm{K}$ extracted by 1 $\mathrm{M} \mathrm{NH}_{4} \mathrm{OAc}$ at $\mathrm{pH} 7$ (Shuman, 1990). The supernatants from each extraction were separated by centrifuging at $6640 \mathrm{~g}$ for 20 minutes and stored in polyethylene containers at $4{ }^{\circ} \mathrm{C}$ prior to analysis. Determinations were made in triplicate. Blank extractions (without soil) were carried out for each set of analyses. The $\mathrm{Ca}, \mathrm{Mg}$, and $\mathrm{Al}$ contents were determined by ICP-AES on a Perkin Elmer OPTIMA 4300DV, K and Na by flame 
emission spectroscopy on an Eppendorf ELEX 6361 instrument, and $\mathrm{Al}_{\mathrm{K}}$ on a Perkin Elmer 403 atomic absorption spectrometer.

The mineralogical compositions of the total $(\leq 2 \mathrm{~mm})$ and clay $(\leq 2 \mu \mathrm{m})$ fractions were identified by X-ray powder diffraction on a Philips X'Pert diffractometer with graphite-monochromated $\mathrm{CuK}_{\alpha}$ radiation. The XRD patterns were obtained from random powder mounts and various oriented aggregates of the $\mathrm{Mg}$ - and $\mathrm{K}$ - clay (airdried, ethylene glycol-solvated, heated at $300{ }^{\circ} \mathrm{C}$ for 3 hours, and heated at $500{ }^{\circ} \mathrm{C}$ for 3 hours). We obtained semi-quantitative estimates of the minerals from random powder and oriented aggregated patterns, using intensity factors reported by Schultz (1964).

\subsection{Sorption experiments}

Both kinetic and isotherm experiments of $\mathrm{Cd}$ and $\mathrm{Pb}$ from their single and binary mixed solutions were undertaken using a batch equilibrium technique. Batch experiments were performed by adding $15 \mathrm{ml}$ of single- $(\mathrm{Pb}$ or $\mathrm{Cd})$ or binary-metal $(\mathrm{Pb}$

$+\mathrm{Cd}$ ) solutions to duplicate 10 -g soil samples in 50-ml polypropylene centrifuge tubes. Kinetic experiments were performed using four different initial metal concentrations. Each initial solution of both metals in single and binary solutions was prepared with similar total ionic strength (Table 1). Ionic strength (mM) was calculated by:

$$
I=1 / 2 \sum_{i} C_{i} Z_{i}^{2}
$$

where $C_{i}$ is the concentration $\left(\mathrm{mmol} \mathrm{dm}^{-3}\right)$ of the $i$ th species, $Z_{i}$ is its charge and $\sum$ extends over all the ions in solution (Sparks, 1995). In the binary solutions, in order to achieve the same $I$ value of the single solutions, the concentration of each metal was proportional to the molecular weight of the metals. All solutions were prepared from chloride metal salts in a $1 \mathrm{mM} \mathrm{CaCl} 2$ background solution. Given the different metal sorption capacity of the soils and based on preliminary studies, we established similar 
total initial ionic strength of all the solutions for S1 and S3. A different total initial ionic strength solution was used for S2 and S4 (Table 1). Theoretical calculations using MINTEQA2 (USEPA, 1997) indicated that all initial solutions were undersaturated with respect to each metal chloride and hydroxide at the $\mathrm{pH}$ of the solutions. The soil suspensions for each initial metal solution concentration were shaken on an end-overend shaker $(30 \mathrm{rpm})$ in a controlled room temperature $\left(25^{\circ} \mathrm{C} \pm 2\right)$ for $1,5,15,30,60$, $180,300,900$, and $1440(24 \mathrm{~h})$ minutes. The suspensions were centrifuged at $6640 \mathrm{~g}$ for 20 minutes and the supernatants removed by filtration (Whatman No. 42) before the $\mathrm{pH}$ of the solutions were determined and the solutions were analysed for $\mathrm{Cd}$ and $\mathrm{Pb}$ by ICP-AES.

The total amount of metal retained by the solid phases was obtained by

$$
S=\left(C_{o}-C_{t}\right) V / W
$$

where $S$ is the amount of metal sorbed per unit mass of soil $\left(\mu \mathrm{mol} \mathrm{kg} \mathrm{kg}^{-1}\right), C_{o}$ and $C_{t}$ are the metal concentration in the initial solution and after the reaction time in the filtrate, respectively $\left(\mu \mathrm{mol} \mathrm{dm}{ }^{-3}\right), V$ is the volume of solution added $\left(\mathrm{dm}^{-3}\right)$ and $W$ is the airdried mass of soil $(\mathrm{g})$.

For each reaction time, sorption isotherms of the metals from their single and binary solutions were constructed using the data obtained from the kinetic experiments and the resulting sorption data obtained from two additional initial concentrations (Figure 1, Table 1). The corresponding sorption isotherms for each equilibration time were investigated by fitting the experimental data to the Langmuir isotherm given by:

$$
S=\frac{Q k C}{1+k C}
$$

where $S$ is the amount of heavy metal sorbed by the soil solids $\left(\mu \mathrm{mol} \mathrm{kg}{ }^{-1}\right), C$ the equilibrium concentration in solution $\left(\mu \mathrm{mol} \mathrm{dm}{ }^{-3}\right), Q$ the maximum sorption $\left(\mu \mathrm{mol} \mathrm{kg} \mathrm{kg}^{-1}\right)$ and $k$ the bonding energy coefficient (reciprocal $\mu \mathrm{mol} \mathrm{dm}{ }^{-3}$ ) (Kinniburgh, 1986). 
An empirical power function was fitted to experimental data from the kinetic sorption experiments (Kuo and Lotse, 1974; Aharoni and Sparks, 1991; Sparks, 1995) as:

$$
S_{t}=k t^{v}
$$

where $S_{t}$ is the amount of metal retained at time $t\left(\mu \mathrm{mol} \mathrm{dm}{ }^{-3}\right), t$ is the reaction time (min), and $k$ and $v$ are constants and $v$ is positive and less than unity (Sparks and Jardine, 1984; Chien and Clayton, 1980).

The optimal parameter values for both Langmuir and kinetic equations were determined by non-linear regression analysis, on the assumption of a constant relative error as the residuals revealed no systematic deviation. The goodness-of-fit for both the isotherms and kinetic equations was estimated by the coefficient of determination $\left(R^{2}\right)$, the confidence intervals (95\%) of the estimated parameters (CI), and the standard error of the estimate (SE).

\section{Results and discussion}

\subsection{Soil characteristics}

All soils were moderately acidic in the surface horizons with differences between $\mathrm{pH}_{\mathrm{w}}$ and $\mathrm{pH}_{\mathrm{K}}$ close to or greater than 1 . In $\mathrm{S} 1$ and $\mathrm{S} 3, \mathrm{Al}$ accounted for the 70 $\%$ and $64 \%$ of the ECEC, respectively, while Ca was the dominant cation in S2 and S4 accounting for the $52 \%$ and $69 \%$ of the ECEC, respectively. Soils S1 and S3 had the lowest ECEC, $\mathrm{pH}_{\mathrm{w}}$ and clay content while $\mathrm{S} 2$ and $\mathrm{S} 4$ were less acidic and showed higher ECEC and clay content. Soil S4, with the highest organic carbon and clay content had the greatest ECEC value $\left(20 \mathrm{cmol}_{\mathrm{c}} \mathrm{kg}^{-1}\right)$. Other soil properties are shown in Table 2 . 
In addition to the differences in the $\mathrm{pH}$, organic carbon, and clay content, the four soils differed in the mineralogical composition of the clay fraction which also conditions their relative sorptive properties (Table 2). The clay fraction of S1 was dominated by kaolinite and to a lesser extent by illite. Soil S2 contained less kaolinite and more smectite and illite. Both S1 and S2 had similar proportions of phyllosilicates in the $\leq 2 \mathrm{~mm}$ soil fraction and of goethite and haematite in the clay fraction. The greater content of illite and the moderate quantity of smectite, provide S2 with greater exchange capacity than S1, as these minerals have larger net surface charge than kaolinite. Also, the presence of smectite provides S2 with permanent surface charge.

The clay fraction of soil S3 consisted predominantly of illite with less kaolinite than soils S1 and S2. Soil S3 had the lowest clay content $\left(45 \mathrm{~g} \mathrm{~kg}^{-1}\right)$ and the smallest proportion of phyllosilicates in the $\leq 2 \mathrm{~mm}$ soil fraction. This soil also had a $\mathrm{pH}_{\mathrm{w}}$ of 5

with low organic carbon $\left(3 \mathrm{~g} \mathrm{~kg}^{-1}\right)$. As a result, $\mathrm{S} 3$ had the lowest exchange capacity. The clay fraction of soil S4 was dominated by well crystallized smectite and a sizable proportion of illite that provide the soil with permanent surface charge. In addition, this soil exhibited both the largest clay content $\left(230 \mathrm{~g} \mathrm{~kg}^{-1}\right)$ and proportion of phyllosilicates in the $\leq 2 \mathrm{~mm}$ soil fraction which, along with the organic carbon content, justify its largest exchange capacity of the four soils. The presence of smectite as the dominant clay ensures high metal sorption capacity (Veeresh et al., 2003) as it provides the soil with high cation exchange capacity, an established factor regulating the sorption of heavy metals by soils (Kuo and Baker, 1980; Hooda and Alloway, 1998; Gomes et al., 2001; Appel and Ma, 2002).

\subsection{Sorption isotherms.}

Cadmium and $\mathrm{Pb}$ sorption data (1440 minutes reaction time) for both single and 
binary initial solutions, were adequately described by the Langmuir equation with high $R^{2}$ and low values of SE (Figure 1, Table 3). Langmuir parameters $Q$ and $k$ were not correlated. Soils S1 and S3 had lower metal sorption capacity than S2 and S4 in terms of the estimated maximum sorption parameter $Q\left(Q_{\mathrm{Pb}}\right.$ and $Q_{\mathrm{Cd}}$ for single metal solutions, and $Q_{\mathrm{Pb}}^{*}$ and $Q^{*}$ Cd, for binary metal solutions) (Table 3 ). This would be expected given the $\mathrm{pH}$, clay content, and its mineralogical composition of the soils (Table 2). Soil S4 had the highest $Q$ values, that would also be expected due to the higher organic matter and clay contents, as well as, the clay mineralogical composition (high proportion of smectite) (Table 2). Soil S3 contained $71 \%$ sand, a clay fraction characterized by a low exchange capacity, low organic matter, and the lowest $\mathrm{pH}$. Accordingly, this soil generally had the lowest $Q$ values (except for $Q^{*}$ Cd in $\mathrm{S} 1$ ). All soils exhibited similar sorption patterns, with $Q$ values for $\mathrm{Pb}$ higher than for $\mathrm{Cd}$ regardless of whether the metals were applied in single or binary solutions. With the exception of $\mathrm{S} 3$, all soils had ratios $Q_{\mathrm{Pb}} / Q_{\mathrm{Cd}}$ (ranging from 1.2 to 1.8 ) lower than ratios $Q_{\mathrm{Pb}}^{*} / Q^{*}$ (ranging from 2.1 to 3.4 ). In the case of $\mathrm{S} 3$, both ratios were more similar than in the other soils (1.8 and 1.5 for single and binary solutions, respectively). This confirms the higher affinity of $\mathrm{Pb}$ than $\mathrm{Cd}$ for sorbent surfaces generally found in both pure soil components and heterogeneous soils (Kinniburgh et al., 1976; Elliott et al., 1986; Appel and Ma, 2002; Gomes et al., 2001; Adhikari and Singh, 2003; Fontes and Gomes, 2003).

The $Q_{\mathrm{i}} / Q^{*}{ }_{\mathrm{i}}$ ratios were generally greater than unity (except for in $\mathrm{S} 3$ ) suggesting that the simultaneous presence of both metals reduced sorption through competition for sorption sites in the solid phases. In addition, it was generally true that $Q_{\mathrm{Cd}} / Q^{*}{ }_{\mathrm{Cd}}>$ $Q_{\mathrm{Pb}} / Q_{\mathrm{Pb}}^{*}$ suggesting that Cd sorption was more affected by the simultaneous presence of a competing metal than $\mathrm{Pb}$. This tendency of $\mathrm{Pb}$ to effectively compete for sorption sites 
on different colloidal surfaces has been described in the presence of $\mathrm{Cd}$ (Fontes and Gomes, 2003; Rodríguez-Maroto et al., 2003), Cu (Christl and Kretzschmar, 1999), and other metals in multimetal solutions (Fontes et al., 2000; Trivedi et al., 2001; Saha et al., 2002). At low concentrations, no competition between $\mathrm{Pb}$ and other metals were observed in other cases (Benjamin and Leckie, 1981a; Saha et al., 2002). In the case of $\mathrm{S} 3, Q_{\mathrm{Cd}} / Q^{*}{ }_{\mathrm{Cd}}$ and $Q_{\mathrm{Pb}} / Q_{\mathrm{Pb}}^{*}$ ratios were similar and smaller than unity.

The bonding energy coefficient $\left(k_{\mathrm{Pb}}\right.$ and $k_{\mathrm{Cd}}$ for single metal solutions, and $k_{\mathrm{Pb}}^{*}$ and $k^{*}$ Cd, for binary metal solutions) varied with soil type and metal solution, although all soils showed greater affinity for $\mathrm{Pb}$ than for $\mathrm{Cd}$ as $k_{\mathrm{Pb}}>k_{\mathrm{Cd}}$ and $k_{\mathrm{Pb}}^{*}>k_{\mathrm{Cd}}^{*}$ (Table 3). Adhikari and Singh (2003) found similar results for single metal solutions, RodríguezMaroto et al. (2003) for both single and binary solutions, and this result also agrees with the generally accepted metal affinity series for soils and soil components (Elliott et al., 1986). However, in contrast to those authors but in agreement with (Mesquita and Viera e Silva, 2002) for competitive sorption of $\mathrm{Cu}$ and $\mathrm{Zn}$, our study found $k_{\mathrm{i}} \leq k_{\mathrm{i}}^{*}$ in all soils except for in soil S3. While binding strength, or affinity constant $(k)$, estimates made from sorption isotherms should only be considered qualitatively (Harter, 1984; Sparks, 1995), they have been related to the free energy change of adsorption of different species (Van Riemsdijk et al., 1985). Higher $k$ values have been related to specifically sorbed metals at high energy surfaces with low dissociation constants. Alternatively, lower $k$ values appear to be related to sorption at low energy surfaces with high dissociation constants (Ma and Rao, 1997; Adhikari and Singh, 2003). The bimetal isotherm $k$ values in all soils except for $\mathrm{S} 3$, may indicate that competition for sorption sites promotes the retention of both metals on more specific sorption positions. As a result, although maximum sorption coefficient $\left(Q_{\mathrm{i}}\right)$ decreases, the metals are held more strongly. The irregular sorptive behavior of S3 in this regard could be explained by the 
high metal load relative to its low sorption capacity as measured by the ECEC. Thus, the estimated $k_{\mathrm{i}}^{*}$ values decreased as a consequence of the increased sorption levels (McBride, 1999).

In order to examine the role of soil $\mathrm{pH}$ and hydrolysis, the sorption data were also plotted against the $\mathrm{pH}$ of the filtrated solutions after the equilibration time of $24 \mathrm{~h}$ and fitted to an exponential growth function linearized as

$$
\ln S=m p H+b
$$

where $S$ is the amount of heavy metal sorbed by the soil solids $\left(\mu \mathrm{mol} \mathrm{kg}{ }^{-1}\right)$ and, $m$ and $b$ the slope and intercept, respectively. Similar to Mesquita and Vieira e Silva (2002), Fontes and Gomes, (2003), and Rodriguez-Maroto et al., (2003), the pH of the filtrated solutions consistently decreased with the sorption level $\left(S_{\mathrm{i}}\right)$ yielding negative values of the slope in equation 5 (Table 4). This has been attributed to metal hydrolysis and the displacement of exchangeable $\mathrm{H}^{+}$by the metal cations. However, in the single metal isotherms the slopes (Eq. 5) for $\mathrm{Pb}$ in the soils in this study were less negative than for Cd (Table 5). This may be due to the greater dependency for Cd retention on electrostatic interactions with exchange sites than $\mathrm{Pb}$, where sorption is more dependent on the covalent interactions with the mineral structures (McBride, 1989; Appel and Ma, 2002).

In contrast, in the binary solutions, the slope for $\mathrm{Pb}$ tended to be slightly more negative than for $\mathrm{Cd}$. In this case, the effect of the sorption of each metal on the final $\mathrm{pH}$ at equilibrium is difficult to assess in these experimental conditions. However, it has been stated that strongly adsorbing cations compete more efficiently with protons in acquiring their position in the electronic clouds of $\mathrm{O}$ atoms than do the weakly adsorbing cations (Abd-Elfattah and Wada, 1981). On the other hand, the value of the slopes for S1 and S3 were always less negative than those for S2 and S4 in both Pb and 
$\mathrm{Cd}$ from single metal solutions. This difference may be the result of the higher $\mathrm{pH}$ and the greater clay content of S2 and S4. This last difference could induce a lowering of the $\mathrm{pH}$ attributed to enhanced hydrolysis of the metals to a greater extend than in S1 and S3 (McBride, 1989). However, this tendency was reversed for the binary metal solutions and we are unable to offer any explanation for this result.

\subsection{Sorption kinetics}

The kinetics of $\mathrm{Pb}$ and $\mathrm{Cd}$ sorption at all initial concentrations and from both single and binary solutions showed a two stage time-dependent behavior with an initially rapid reaction followed by a much slower phase, although some differences were observed between the metals, solutions, and the soils (Figure 2). Lead was initially more rapidly sorbed than $\mathrm{Cd}$ in all soils and from both single and binary solutions (Rodríguez-Maroto et al., 2003) . For example, from the single solution of the lowest concentration and at an equilibration time of $15 \mathrm{~min}$, more than $99 \%$ of the initial $\mathrm{Pb}$ concentration was sorbed in S1, S2 and S4, and $96 \%$ in S3. In contrast, under similar conditions, Cd sorption reached the $77 \%$ of the initial concentration in S1, S2, and S3, and $91 \%$ in S4. While these percentages did not vary for $\mathrm{Pb}$ from binary solutions, $\mathrm{Cd}$ sorption at $15 \mathrm{~min}$ increased, resulting in more than $87 \%$ of the initial concentration in all soils. Overall, this initial rapid reaction that both metals underwent in single and binary solutions is characteristic of heavy metal sorption on pure components and soils and has been attributed to chemisorption on phyllosilicates (Eick et al., 2001), adsorption on high affinity surface sites (Glover et al., 2002), or on sites with higher bonding strength with the metal (McBride, 1999). Consequently, the increment in the initial $\mathrm{Cd}$ sorption rate in binary solutions could indicate that the competitive $\mathrm{Pb}$ sorption forces $\mathrm{Cd}$ retention on sorption sites with greater affinity or more specific for 
this metal. However, the sorption mechanisms responsible for the slow reaction phase are not well understood (Glover et al., 2002) although it has been attributed to diffusion, precipitation, and/or sorption reactions on sites with higher activation energy than the fast sorption sites (Strawn and Sparks, 2000). Thus, the apparent rate coefficient of metal sorption reactions are composed of various chemical and diffusive reactions, difficult to differentiate in complex soil matrices from time dependent data without spectroscopic evidence (Glover et al., 2002).

Consequently, a fractional power function (Eq. 4) (Aharoni and Sparks, 1991) was used to compare the overall sorption kinetics of the metals in single and binary solutions. This equation is empirical and therefore its use does not support mechanistic information but simply provide a consistent method to compare experimental results. In general, Equation 4 adequately described the rate of metal sorption within the time ranges used in these experiments and from both single and binary solutions (given the high $R^{2}$ and low SE values).

The estimated exponents of Equation $4(v)$ for $\mathrm{Pb}$ and $\mathrm{Cd}$ sorption from single and binary solutions are listed in Table 5 . These values could be related to the empirical rate coefficients of the overall sorption processes over the entire reaction time range. As can be seen in Table 4, in all soils, the simultaneous presence of the competing metal did not affect the estimated apparent sorption rate $\left(v_{\mathrm{i}} \approx v_{\mathrm{i}}^{*}\right)$ at any initial concentration. This could indicate that among the different sorption processes that take place during the metal interaction with the soil components, the rate limiting factor, although difficult to identify, may not be affected by the presence of the competing metal. On the other hand, although due to the strong affinity of the soil for Pb (Strawn and Sparks, 2000) its sorption was apparently more rapid at short reaction times than Cd sorption, estimated $v$ values for $\mathrm{Pb}$ were consistently smaller than for $\mathrm{Cd}$ in all soils from both 
single and binary solutions over the entire reaction time range $\left(v_{\mathrm{Cd}}>v_{\mathrm{Pb}}\right.$ and $\left.v_{\mathrm{Cd}}{ }^{*}>v_{\mathrm{Pb}}{ }^{*}\right)$. This could be related to the greater tendency of $\mathrm{Pb}$ to be adsorbed as a hydrolyzed species than $\mathrm{Cd}$ (Glover et al., 2002), which limits the rate of $\mathrm{Pb}$ diffusion into micropores created by structural defects of the clay particles (Glover et al., 2002) or into the narrow interlayer space of 2:1 clay minerals (McBride, 1994). Finally, estimated apparent sorption rates for each metal from single and binary solutions are similar in soils S1, S2, and S3 and about one order of magnitude lower in S4 than in the rest of the soils. As described above, the mineralogical composition of soils S1, S2, and S3 is dominated by kaolinite and illite, whereas, the clay fraction of soil S4 is dominated by smectite. Metal sorption on kaolinite and illite does not differ much (Lackovic et al., 2004) and it is known to be a rapid reaction since their exchange capacities are mainly due to external surface and edge sites readily accessible to cation exchange (Jardine and Sparks, 1984). In fact, cation exchange on clays without narrow interlayer space such as kaolinite appears to be instantaneous in comparison to exchange on smectite which can be related to its freely expanding interlayer space (Jardine and Sparks, 1984) and limited by the rate of cation diffusion through this region (McBride, 1994).

This different sorptive behavior of the soils as a function of the clay mineralogical composition can be observed when sorption isotherms are constructed for each equilibration time ( 1 to 1440 minutes). The estimated $Q$ values from fitting the Langmuir equation to all of the isotherms were plotted against the equilibration time for each soil and metal in both single and binary solutions. An empirical power function was found to adequately describe the resulting $Q(\mathrm{t})$ plots with $R^{2}$ values ranging from 0.83 to 0.99 . The exponents of each function $Q(\mathrm{t})$ along with the corresponding $R^{2}$ values, confidence intervals of the estimated exponents, and the standard error of the estimate are shown in Table 6. The average value of the exponents found for S1, S2, 
and $\mathrm{S} 3$, were $0.03 \pm 0.015$ (standard deviation) and $0.035 \pm 0.003$ for $\mathrm{Pb}$, and $0.042 \pm 0.017$ and $0.040 \pm 0.019$ for $\mathrm{Cd}$, in single and binary solutions, respectively. These values are lower than those found for soil S4. Based on this, it seems that the time-evolution of the $Q$ value can also be related to clay mineralogical composition to a greater extent than to whether $\mathrm{Pb}$ and $\mathrm{Cd}$ are applied in single or binary solutions.

\section{Conclusions}

We performed a detailed investigation of competitive sorption processes between $\mathrm{Pb}$ and $\mathrm{Cd}$ metals using batch sorption isotherms and kinetics sorption studies for single and binary metal solutions in four soils. Sorption isotherms for $\mathrm{Pb}$ and $\mathrm{Cd}$ in single and binary solutions of similar total ionic strength were adequately described by Langmuir equation. The sorption capacity of the soils for lead, as measured by the estimated $Q$ parameter from Langmuir equation, is greater than for cadmium. The coexistence of both metals reduces their tendency to be sorbed on the soil solid phases affecting, to a greater extent, the sorption capacity of $\mathrm{Cd}$ than $\mathrm{Pb}$. Soils $\mathrm{S} 2$ and $\mathrm{S} 4$, with higher $\mathrm{pH}$ and clay content characterized by having sizable proportions of smectite, had the greatest metal sorption capacity as the presence of this clay mineral provides the soil with a large cation exchange capacity. On the other hand, in agreement with the metal affinity series, the binding strength parameter $k$ was always greater for lead than for cadmium. However, in all soils (except for the S3) the simultaneous presence of both metals increased their corresponding $k$ values indicating that competition for sorption sites could promote the retention of both metals on more specific sorption positions, although the amount of metal retained in the soil decreased. Therefore, results from an assessment of the potential bioavailability and toxicity of lead and cadmium might be different whether the experiments are performed using single or binary solutions. 
The kinetics of $\mathrm{Pb}$ and $\mathrm{Cd}$ sorption from both single and binary solutions followed a two stage time-dependent behavior with an initially rapid reaction followed by a much slower stage. This sorption kinetic could be well described by an empirical power function within the reaction time ranges used in this study. The estimated apparent sorption rates of the metals from single and binary solutions were similar. This result could indicate that the rate limiting metal sorption stage in these soils for each metal is not significantly affected by the simultaneous presence of both species. On the other hand, $\mathrm{Pb}$ was initially more rapidly sorbed than $\mathrm{Cd}$ in all soils and from both single and binary solutions. However, the estimated exponents were in all cases smaller for $\mathrm{Pb}$ than for $\mathrm{Cd}$, likely due to diffusion processes into micropores or interlayer clay spaces for which $\mathrm{Cd}$ could exhibit greater ease than $\mathrm{Pb}$. Finally, the mineralogical composition of the clay fraction of these soils determined the empirical metal sorption rate within the time ranges employed in this study. The overall sorption processes of $\mathrm{Pb}$ and $\mathrm{Cd}$ in the smectitic soil S4, with the highest sorption capacity of the soils are slower than in the rest of the soils with a clay mineralogy dominated by kaolinite and illite.

From these results, it can be concluded that the sorption behavior of $\mathrm{Pb}$ and $\mathrm{Cd}$ in the moderate acidic soils is significantly affected by the simultaneous presence of both metals. Thus, the competitive sorption should be considered to correctly assess their potential bioavailability, toxicity, and leachability in soils.

\section{Acknowlegments.}

This work was supported by the Spanish Ministry of Science and Technology within the framework of the research project BTE2003-01949. The authors wish to thank Tim Kneafsey for his helpful review of the manuscript. 


\section{References}

Abd-Elfattah, A. and Wada, K., 1981. Adsorption of lead, copper, zinc, cobalt, and cadmium by soils that differ in cation-exchange materiales. Journal of Soil Science, 32: 271-283.

Adhikari, R. and Singh, M.V., 2003. Sorption characterisitics of lead and cadmium in some soils of India. Geoderma, 114: 81-92.

Aharoni, C. and Sparks, D.L., 1991. Kinetics of soil chemical reactions - A theoretical treatment. In: D.L. Sparks and D.L. Suarez (Editors), Rates of soil chemical processes. SSSA Special Publication. SSSA, Inc, Madison, Wisconsin, USA, pp. $1-18$.

Appel, C. and Ma, L., 2002. Concentration, pH, and surface charge effects on Cadmium and Lead sorption in three tropical soils. Journal Enviromental Quality, 31: 581589.

Barnhisel, R. and Bertsch, P.M., 1982. Aluminum. In: A.L. Page (Editor), Methods of Soil Analysis. Part 2. Chemical and Microbiological Properties. American Society of Agronomy, Madison, WI, pp. 275-300.

Benjamin, M.M. and Leckie, J.O., 1981a. Competitive adsorption of $\mathrm{Cd}, \mathrm{Cu}, \mathrm{Zn}$, and $\mathrm{Pb}$ on amorphous iron oxyhydroxide. Journal of Colloid and Interface Science, 83: 410-419.

Benjamin, M.M. and Leckie, J.O., 1981b. Multiple-site adsorption of Cd, Cu, Zn, and $\mathrm{Pb}$ on amorphous iron oxyhydroxide. Journal of Colloid and Interface Science, 79: $209-221$. 
Bereket, G., Aroguz, A.Z. and Özel, M.Z., 1997. Removal of Pb(II), Cu(II), and Zn(II) from aqueous solutions by adsorption on bentonite. Journal of Colloid and Interface Science, 187: 338-343.

Cavallaro, N. and McBride, M.B., 1978. Copper and cadmium adsorption characteristics of selected acid and calcareous soils. Soil Science Society of America Journal, 42: 550-556.

Chen, X., Wright, J.V., Conca, J.L. and Peurrung, L.M., 1997. Effects of pH on heavy metal sorption on mineral apatite. Environmental Science and Technology, 31: 624-631.

Chien, S.H. and Clayton, W.R., 1980. Application of Elovich equation to the kinetics of phosphate release and sorption in soils. Soil Science Society of America Journal, 44: $265-268$.

Christl, I. and Kretzschmar, R., 1999. Competitive sorption of copper and lead at the oxide-water interface: Implications for surface site density. Geochimica et Cosmochimica Acta, 63: 2929-2938.

Eick, M.J., Naprstek, B.R. and Brady, P.V., 2001. Kinetics of Ni(II) sorption and desorption on kaolinite: residence time effects. Soil Science, 166(1): 11-17.

Elliott, H.A., Liberati, M.R. and Huang, C.P., 1986. Competitive adsorption of heavy metals by soils. Journal of Environmental Quality, 15(3): 214-219.

Fontes, M.P.F., de Matos, A.T., da Costa, C.L. and Neves, J.C.L., 2000. Competitive adsorption of zinc, cadmium, copper, and lead in three highly-weathered Brazilian soils. Communications in Soil Science and Plant Analysis, 31: 29392958. 
Fontes, M.P.F. and Gomes, P.C., 2003. Simultaneous competitive adsorption of heavy metals by the mineral matrix of tropical soils. Applied Geochemistry, 18: 795804.

Förstner, U., 1995. Land contamination by metals: Global scope and magnitude of problem. In: H.E. Allen, C.P. Huang, G.W. Bailey and A.R. Bowers (Editors), Metal Speciation and Contamination of Soil. Lewis Publishers, Boca Raton, pp. $1-33$.

Glover, L.J., II, Eick, M.J. and Brady, P.V., 2002. Desorption kinetics of cadmium ${ }^{2+}$ and lead ${ }^{2+}$ from goethite: influence of time and organic acids. Journal of Environmental Quality, 66: 797-804.

Gomes, P.C., Fontes, M.P.F., da Silva, A.G., Mendoca, E.S. and Netto, A.R., 2001. Selectivity sequence and competitive adsorption of heavy metals by Brazilian soils. Soil Science Society of America Journal, 65: 1115-1121.

Harter, R.D., 1984. Curve-fit errors in Langmuir adsorption maxima. Soil Science Society of America Journal, 48: 749-752.

Harter, R.D., 1992. Competitive sorption of cobalt, copper, and nickel ions by a calcium-saturated soil. Soil Science Society of America Journal, 56: 444-449.

Harter, R.D. and Naidu, R., 2001. An assessment of environmental and solution parameter impact on trace-metal sorption by soils. Soil Science Society of America Journal, 65: 597-612.

Hooda, P.S. and Alloway, B.J., 1994. Sorption of $\mathrm{Cd}$ and $\mathrm{Pb}$ by selected temperate and semi-arid soils: effects of sludge application and ageing of sludge soils. Water, Air, and Soil Pollution, 74: 235-250.

Hooda, P.S. and Alloway, B.J., 1998. Cadmium and lead sorption behaivior of selected English and Indian soils. Geoderma, 84: 121-134. 
Jardine, P.M. and Sparks, D.L., 1984. Potassium-Calcium exchange in a multireactive soil system: I. Kinetics. Soil Science Society of America Journal, 48: 39-45.

Kinniburgh, D.G., 1986. General purpose adsorption isotherms. Environmental Science and Technology, 20: 895-904.

Kinniburgh, D.G., Jackson, M.L. and Syers, J.K., 1976. Adsorption of alkaline earth, transition, and heavy metal cations by hydrous oxide gels of iron and aluminum. Soil Science Society of America Journal, 40: 796-799.

Kookama, R.S. and Naidu, R., 1998. Effect of soil solution composition on cadmium transport through variable charge soils. Geoderma, 84: 235-248.

Krishnamurti, G.S.R. and Naidu, R., 2003. Solid-solution equilibria of cadmium in soils. Geoderma, 113: 17-30.

Kuo, S. and Baker, A.S., 1980. Sorption of copper, zinc, and cadmium by some acid soils. Soil Science Society of America Journal, 44: 969-974.

Kuo, S. and Lotse, E.G., 1974. Kinetics of phosphate adsorption ond desorption by lake sediments. Soil Science Society of America Proceeding, 38: 50-54.

Lackovic, K., Wells, J.D., Johnson, B.B. and Angove, M.J., 2004. Modeling the adsorption of Cd(II) onto kaolinite and Muloorina illite in the presence of citric acid. Journal of Colloid and Interface Science, 270: 86-93.

Ma, L.Q. and Rao, G.N., 1997. Chemical fractionation of Cadmium, Copper, Nickel, and Zinc in contaminated soils. Journal of Environmental Quality, 26: 259-264.

Martínez, C.E. and McBride, M.B., 1998. Solubility of $\mathrm{Cd} 2+, \mathrm{Cu} 2+, \mathrm{Pb} 2+$, and $\mathrm{Zn} 2+$ in aged coprecipitates with amorphous iron hydroxides. Environmental Science and Technology, 32: 743-748.

McBride, M.B., 1989. Reactions controlling heavy metals solubility in soils. Advances in Soil Science, 10: 1-56. 
McBride, M.B., 1994. Environmental Chemistry of Soils. Oxford University Press, New York, 406 pp.

McBride, M.B., 1999. Chemisorption and precipitation reactions. In: M.E. Sumner (Editor), Handbook of Soil Science. CRC Press, Boca Raton, pp. B265-B302.

Mesquita, M.E. and Viera e Silva, J.M., 2002. Preliminary study of pH effect in the application of Langmuir and Freundlich isotherms to $\mathrm{Cu}-\mathrm{Zn}$ competitive adsorption. Geoderma, 106: 219-234.

Murali, V. and Aylmore, L.A.G., 1983. Competitive adsorption during solute transport in soils: I. Mathematical models. Soil Science, 135(3): 143-150.

Pinheiro, J.P., Mota, A.M. and Benedetti, M.F., 1999. Lead and calcium binding to fulvic acids: Salt effect and competition. Environmental Science and Technology, 33: 3398-3404.

Rodríguez-Maroto, J.M. et al., 2003. Competitive retention of lead and cadmium on an agricultural soil. Environmental Monitoring and Assessment, 89: 165-177.

Saha, U.K., Taniguchi, S. and Sakurai, K., 2002. Simultaneous adsorption of cadmium, zinc, and lead on hydroxyalumium- and hydroxyaluminosilicate-montmorillinite complexes. Soil Science Society of America Journal, 66: 117-128.

Sauvé, S., Hendershot, W. and Allen, H.E., 2000. Solid-solution partitioning of metals in contaminated soils: dependence on $\mathrm{pH}$, total metal burden, and organic matter. Environmental Science and Technology, 34: 1125-1131.

Schultz, L. G. 1964. Quantitative interpretation of mineralogical composition from Xray and chemical data for the Pierre Shale. U. S. Geological Survey Professional Paper, 391-C: C1-C31.

Shuman, L.M., 1990. Comparison of exchangeable Al, extractable Al, and Al in soil fractions. Canadian Journal of Soi Science, 70: 263-275. 
Soil Survey Staff. 1999. A Basic System of Soil Classification for Making and Interpreting Soil Surveys. Agriculture Handbook 436. U. S. Government Printing Office, Washington, DC.

Sparks, D.L., 1995. Environmental soil chemistry. Academic Press, Inc, San Diego, California, $267 \mathrm{pp}$.

Sparks, D.L. and Jardine, P.M., 1984. Comparison of kinetics equations to describe potassium-calcium exchange in pure and in mixed systems. Soil Science, 138(2): 115-122.

Strawn, D.G. and Sparks, D.L., 2000. Effects of soil organic matter on the kinetics and mechanisms of $\mathrm{Pb}$ (II) sorption and desorption in soil. Soil Science Society of America Journal, 64: 144-156.

Tiller, K.G., Gerth, J. and Brümmer, G., 1984. The sorption of Cd, Zn and Ni by soil clay fractions: procedures for partition of bound forms and their interpretation. Geoderma, 34: 1-16.

Tiller, K.G., Nayyar, V.K. and Clayton, P.m., 1979. Specific and Non-specific sorption of Cadmium by soil clays as influenced by Zinc and Calcium. Australian Journal of Soil Research, 17: 17-28.

Thomas, G. W. 1982. Exchangeable Cations. In: A. L. Page et al. (Editors), Methods of Soil Analysis, Part 2. Chemical and Microbiological Properties. American Society of Agronomy, Madison, WI, pp. 159-164.

Trivedi, P., Axe, L. and Dyer, J., 2001. Adsorption of metal ions onto goethite: singleadsorbate and competitive systems. Colloids and Surfaces A: Physicochemical and Engineering Aspects, 191: 107-121. 
Trivedi, P., Dyer, J.A. and Sparks, D.L., 2003. Lead sorption onto Ferrihydrite. 1. A macroscopic and spectroscopic assessment. Environmental Science and Technology, 37: 908-914.

U. S. Environmental Protection Agency. 1997. MINTEQA2/PRODEFA2 geochemical code. USEPA, Environmental Research Laboratory, Athens, GA.

Van Riemsdijk, W.H., Bolt, G.H., Koopal, L.k. and Blaakmeer, J., 1985. Electrolyte adsorption on heterogeneous surfaces: adsorption models. Journal of Colloid and Interface Science, 109: 219-228.

Veeresh, H., Tripathy, S., Chaudhuri, D., Hart, B.R. and Powell, M.A., 2003. Sorption and distribution of adsorbed metals in three soils of India. Applied Geochemistry, 18: 1723-1731.

Walkley, A. and Black, A.I., 1934. An examination of the Degtjareff method for determining soil organic matter, and a proposed modification of the chromic acid titration method. Soil Science, 37: 29-38.

Welp, G. and Brümmer, G.W., 1999. Adsorption and solubility of ten metals in soil samples of different composition. Journal of Plant Nutrition and Soil Science, 162: $155-161$. 


\section{Figure captions}

\section{Figure 1.}

Lead and cadmium sorption isotherms from both single (open symbols) and binary (closed symbols). Solid lines are the best fits to the Langmuir equation.

\section{Figure 2.}

Sorption kinetics of lead and cadmium from single and binary solutions of varying initial concentrations in S1 and S2. 
Table 1

Initial metal concentrations and total ionic strength used in the sorption isotherms and kinetic sorption experiments

\begin{tabular}{|c|c|c|c|c|c|c|c|c|}
\hline & \multicolumn{2}{|c|}{ S1 } & \multicolumn{2}{|c|}{ S2 } & \multicolumn{2}{|c|}{ S3 } & \multicolumn{2}{|c|}{ S4 } \\
\hline & $\begin{array}{c}\mathrm{C}_{\mathrm{o}} \\
\mathrm{mM}\end{array}$ & $\begin{array}{c}\operatorname{Total}^{\mathrm{a}} \mathrm{I}_{\mathrm{o}} \\
\mathrm{mM}\end{array}$ & $\begin{array}{c}\mathrm{C}_{\mathrm{o}} \\
\mathrm{mM}\end{array}$ & $\begin{array}{c}\text { Total } \mathrm{I}_{\mathrm{o}} \\
\mathrm{mM}\end{array}$ & $\begin{array}{c}\mathrm{C}_{\mathrm{o}} \\
\mathrm{mM}\end{array}$ & $\begin{array}{c}\text { Total } \mathrm{I}_{\mathrm{o}} \\
\mathrm{mM}\end{array}$ & $\begin{array}{c}\mathrm{C}_{\mathrm{o}} \\
\mathrm{mM} \\
\end{array}$ & $\begin{array}{c}\text { Total } \mathrm{I}_{\mathrm{o}} \\
\mathrm{mM}\end{array}$ \\
\hline \multirow[t]{6}{*}{$\mathrm{Pb}$} & $0.02^{*}$ & 3.07 & $0.89^{*}$ & 5.68 & $0.02^{*}$ & 3.07 & 4.15 & 15.45 \\
\hline & $0.07^{*}$ & 3.20 & $1.85^{*}$ & 8.54 & $0.07^{*}$ & 3.20 & 5.55 & 19.65 \\
\hline & 0.14 & 3.43 & 4.15 & 15.45 & 0.14 & 3.43 & 7.14 & 24.43 \\
\hline & 0.35 & 4.04 & 5.55 & 19.65 & 0.35 & 4.04 & 11.92 & 38.76 \\
\hline & 0.89 & 5.68 & 7.14 & 24.43 & 0.89 & 5.68 & $15.84^{*}$ & 50.51 \\
\hline & 1.85 & 8.54 & 10.14 & 33.41 & 1.85 & 8.54 & $18.54^{*}$ & 58.62 \\
\hline \multirow[t]{6}{*}{$\mathrm{Cd}$} & $0.04^{*}$ & 3.11 & $0.04^{*}$ & 3.11 & $0.04^{*}$ & 3.11 & $1.90^{*}$ & 8.69 \\
\hline & $0.09^{*}$ & 3.26 & $0.06^{*}$ & 3.17 & $0.09^{*}$ & 3.26 & $2.74^{*}$ & 11.21 \\
\hline & 0.19 & 3.56 & 3.58 & 13.75 & 0.19 & 3.56 & 3.61 & 13.83 \\
\hline & 0.33 & 3.98 & 5.33 & 19.00 & 0.36 & 4.07 & 6.28 & 21.83 \\
\hline & 0.89 & 5.66 & 6.82 & 23.45 & 0.89 & 5.66 & 8.22 & 27.65 \\
\hline & 1.78 & 8.33 & 10.84 & 35.52 & 1.78 & 8.33 & 9.64 & 31.92 \\
\hline \multirow[t]{6}{*}{$\mathrm{Pb}(+\mathrm{Cd})$} & 0.11 & 3.51 & $0.62^{*}$ & 5.84 & 0.11 & 3.51 & 2.83 & 16.36 \\
\hline & 0.24 & 4.10 & $1.17^{*}$ & 8.47 & 0.24 & 4.10 & 3.57 & 20.29 \\
\hline & 0.62 & 5.84 & 2.83 & 16.17 & 0.62 & 5.98 & 5.12 & 28.15 \\
\hline & 1.17 & 8.47 & 3.76 & 20.86 & 1.17 & 8.71 & 7.48 & 39.96 \\
\hline & $2.83^{*}$ & 16.36 & 4.34 & 24.33 & $2.56^{*}$ & 15.55 & $9.51^{*}$ & 50.05 \\
\hline & $3.57^{*}$ & 20.29 & 7.14 & 39.94 & $3.57^{*}$ & 24.65 & $11.26^{*}$ & 58.55 \\
\hline \multirow[t]{6}{*}{$\mathrm{Cd}(+\mathrm{Pb})$} & 0.06 & 3.51 & $0.33^{*}$ & 5.84 & 0.06 & 3.51 & 1.62 & 16.36 \\
\hline & 0.13 & 4.10 & $0.65^{*}$ & 8.47 & 0.13 & 4.10 & 2.19 & 20.29 \\
\hline & 0.33 & 5.84 & 1.56 & 16.17 & 0.37 & 5.98 & 3.27 & 28.15 \\
\hline & 0.65 & 8.47 & 2.19 & 20.86 & 0.74 & 8.71 & 4.84 & 39.96 \\
\hline & $1.62^{*}$ & 16.36 & 2.76 & 24.33 & $1.62^{*}$ & 15.55 & $6.18^{*}$ & 50.05 \\
\hline & $2.19^{*}$ & 20.29 & 5.17 & 39.94 & $3.64^{*}$ & 24.65 & $7.26^{*}$ & 58.55 \\
\hline
\end{tabular}

${ }^{\text {a }}$ Total ionic strength of the solution as calculated by eq. 1

* Initial concentrations followed by * were used as additional solutions for the sorption isotherm experiments. 
Table 2 .

Physical and chemical properties of the experimental soils

\begin{tabular}{|c|c|c|c|c|c|c|c|c|c|c|c|c|}
\hline \multirow[b]{2}{*}{ Soil No. } & \multirow[b]{2}{*}{$\mathrm{pH}_{\mathrm{w}}{ }^{\mathrm{a}}$} & \multirow[b]{2}{*}{$\mathrm{pH}_{\mathrm{k}}{ }^{\mathrm{b}}$} & \multirow{2}{*}{$\begin{array}{c}\text { OC } \\
\mathrm{g} \mathrm{kg}^{-1} \\
\end{array}$} & $\mathrm{Ca}$ & $\mathrm{Mg}$ & $\mathrm{Na}$ & $\mathrm{K}$ & $\mathrm{Al}$ & ECEC & Sand & Silt & Clay \\
\hline & & & & \multicolumn{6}{|c|}{$\mathrm{cmol}_{\mathrm{c}} \mathrm{kg}^{-1}$} & \multicolumn{3}{|c|}{$\mathrm{g} \mathrm{kg}^{-1}$} \\
\hline $\mathrm{S} 1^{\mathrm{c}}$ & $5.2(0.02)$ & $4.2(0.03)$ & $17(1.0)$ & $0.32(0.02)$ & $0.08(0.00)$ & $0.04(0.00)$ & $0.09(0.00)$ & $1.26(0.08)$ & $1.79(0.11)$ & $675(38)$ & $250(15)$ & $75(5)$ \\
\hline S2 & $6.1(0.05)$ & $4.5(0.02)$ & $12(0.6)$ & $1.58(0.04)$ & $0.49(0.01)$ & $0.07(0.01)$ & $0.68(0.12)$ & $0.19(0.01)$ & $3.01(0.18)$ & $643(35)$ & $201(13)$ & $156(12)$ \\
\hline S3 & $5.0(0.02)$ & $3.8(0.01)$ & $3(0.1)$ & $0.06(0.00)$ & $0.20(0.02)$ & $0.02(0.00)$ & $0.11(0.01)$ & $0.7(0.03)$ & $1.09(0.05)$ & $710(42)$ & $245(16)$ & $45(6)$ \\
\hline $\mathrm{S} 4$ & $5.8(0.03)$ & $4.3(0.02)$ & $61(6.5)$ & $14.10(0.58)$ & $5.22(0.50)$ & $0.21(0.03)$ & $0.39(0.02)$ & $0.56(0.05)$ & $20.5(1.25)$ & $560(25)$ & $210(8)$ & $230(19)$ \\
\hline
\end{tabular}

Semi-quantitative mineralogical composition (relative \% between samples) of the soils.

\begin{tabular}{ccccccccccccc}
\hline Fraction & Soil No & $\mathrm{Q}$ & $\mathrm{F}_{\mathrm{Ca}-\mathrm{Na}}$ & $\mathrm{F}_{\mathrm{K}}$ & $\mathrm{G}$ & $\mathrm{H}$ & $\mathrm{Ph}$ & $\mathrm{S}$ & $\mathrm{V}$ & $\mathrm{I}$ & $\mathrm{K}$ \\
\hline \multirow{2}{*}{$\leq 2 \mathrm{~mm}$} & $\mathrm{~S} 1$ & 74 & $\operatorname{tr}$ & $\operatorname{tr}$ & 4 & 3 & 19 & - & - & - & - \\
& $\mathrm{S} 2$ & 80 & $\operatorname{tr}$ & $\operatorname{tr}$ & $\operatorname{tr}$ & $\mathrm{nd}$ & 20 & - & - & - & - \\
& $\mathrm{S} 3$ & 52 & 8 & 31 & $\mathrm{nd}$ & $\mathrm{nd}$ & 9 & - & - & - & - \\
& $\mathrm{S} 4$ & 40 & 18 & 9 & $\mathrm{nd}$ & $\mathrm{nd}$ & 33 & - & - & - & - \\
$\leq 2 \mu \mathrm{m}$ & $\mathrm{S} 1$ & 12 & $\mathrm{nd}$ & $\mathrm{nd}$ & 6 & 6 & 76 & $\mathrm{nd}$ & 8 & 11 & 57 \\
& $\mathrm{~S} 2$ & 22 & $\mathrm{nd}$ & $\mathrm{nd}$ & 7 & 3 & 68 & 14 & $\mathrm{nd}$ & 22 & 32 \\
& $\mathrm{~S} 3$ & 13 & 5 & 4 & $\mathrm{nd}$ & $\mathrm{nd}$ & 78 & $\mathrm{nd}$ & $\mathrm{nd}$ & 52 & 26 \\
& $\mathrm{~S} 4$ & 4 & nd & nd & nd & nd & 96 & 48 & nd & 36 & 12 \\
\hline
\end{tabular}

$\mathrm{Q}=$ quartz, $\mathrm{F}_{\mathrm{Ca}-\mathrm{Na}}=$ calcium- and sodium-rich feldspars, $\mathrm{F}_{\mathrm{K}}=$ potassium-rich feldspars, $\mathrm{G}=$ goethite, $\mathrm{H}=$ haematite, $\mathrm{Ph}=$ phyllosilicates, $\mathrm{V}=$ vermiculite, $\mathrm{S}=$ smectite, $\mathrm{I}=$ illite, $\mathrm{K}=$ Kaolinite, $\mathrm{nd}=$ not detected, $\mathrm{tr}=$ traces; - , not determined 
Table 3.

Parameters of Langmuir isotherm at a reaction time of $1440 \mathrm{~min}$.

\begin{tabular}{|c|c|c|c|c|c|c|c|}
\hline & & $Q^{\mathrm{a}}$ & $\mathrm{CI}^{\mathrm{b}}$ & $k$ & $\mathrm{CI}$ & \multirow[t]{2}{*}{$\mathrm{SE}^{\mathrm{c}}$} & \multirow[t]{2}{*}{$R^{2 \mathrm{~d}}$} \\
\hline \multicolumn{2}{|c|}{ Soil No. Metal sol. } & \multicolumn{2}{|c|}{$\mu \mathrm{mol} \mathrm{kg}{ }^{-1}$} & \multicolumn{2}{|c|}{ reciprocal $\mu \mathrm{mol} \mathrm{dm} \mathrm{dm}^{-3}$} & & \\
\hline \multirow[t]{4}{*}{ S1 } & $\mathrm{Pb}$ & $2.92 \times 10^{3}$ & $3.35 \times 10^{2}$ & 0.220 & 0.081 & $1.10 \times 10^{2}$ & 0.99 \\
\hline & $\mathrm{Cd}$ & $2.37 \times 10^{3}$ & $2.25 \times 10^{2}$ & 0.002 & 0.001 & $0.97 \times 10^{2}$ & 0.98 \\
\hline & $\mathrm{Pb}(+\mathrm{Cd})$ & $2.85 \times 10^{3}$ & $3.01 \times 10^{2}$ & 0.204 & 0.090 & $1.05 \times 10^{2}$ & 0.96 \\
\hline & $\mathrm{Cd}(+\mathrm{Pb})$ & $8.03 \times 10^{3}$ & $1.86 \times 10^{2}$ & 0.006 & 0.003 & $0.63 \times 10^{2}$ & 0.96 \\
\hline \multirow[t]{4}{*}{$\mathrm{S} 2$} & $\mathrm{~Pb}$ & $1.29 \times 10^{4}$ & $2.30 \times 10^{3}$ & 0.062 & 0.020 & $1.62 \times 10^{3}$ & 0.91 \\
\hline & $\mathrm{Cd}$ & $7.67 \times 10^{3}$ & $1.57 \times 10^{3}$ & 0.003 & 0.001 & $6.39 \times 10^{2}$ & 0.95 \\
\hline & $\mathrm{Pb}(+\mathrm{Cd})$ & $9.88 \times 10^{3}$ & $1.95 \times 10^{3}$ & 0.083 & 0.031 & $1.01 \times 10^{3}$ & 0.93 \\
\hline & $\mathrm{Cd}(+\mathrm{Pb})$ & $3.36 \times 10^{3}$ & $8.18 \times 10^{2}$ & 0.006 & 0.003 & $2.80 \times 10^{2}$ & 0.95 \\
\hline \multirow[t]{4}{*}{ S3 } & $\mathrm{Pb}$ & $2.33 \times 10^{3}$ & $3.63 \times 10^{2}$ & 0.036 & 0.018 & $1.04 \times 10^{2}$ & 0.99 \\
\hline & $\mathrm{Cd}$ & $1.27 \times 10^{3}$ & $6.99 \times 10^{2}$ & 0.002 & 0.000 & $0.71 \times 10^{2}$ & 0.96 \\
\hline & $\mathrm{Pb}(+\mathrm{Cd})$ & $2.83 \times 10^{3}$ & $6.09 \times 10^{2}$ & 0.012 & 0.002 & $2.44 \times 10^{2}$ & 0.96 \\
\hline & $\mathrm{Cd}(+\mathrm{Pb})$ & $1.86 \times 10^{3}$ & $4.58 \times 10^{2}$ & 0.001 & 0.000 & $0.66 \times 10^{2}$ & 0.96 \\
\hline \multirow[t]{4}{*}{ S4 } & $\mathrm{Pb}$ & $2.52 \times 10^{4}$ & $3.05 \times 10^{3}$ & 0.006 & 0.005 & $1.91 \times 10^{3}$ & 0.95 \\
\hline & $\mathrm{Cd}$ & $1.69 \times 10^{4}$ & $1.08 \times 10^{3}$ & 0.001 & 0.000 & $2.05 \times 10^{2}$ & 1.00 \\
\hline & $\mathrm{Pb}(+\mathrm{Cd})$ & $1.50 \times 10^{4}$ & $2.06 \times 10^{3}$ & 0.013 & 0.015 & $1.58 \times 10^{3}$ & 0.90 \\
\hline & $\mathrm{Cd}(+\mathrm{Pb})$ & $7.29 \times 10^{3}$ & $1.14 \times 10^{3}$ & 0.003 & 0.002 & $3.67 \times 10^{2}$ & 0.97 \\
\hline
\end{tabular}

${ }^{a} Q$ is the maximum sorption capacity, $k$ the bonding energy coefficient.

${ }^{\mathrm{b}} \mathrm{CI}, 95 \%$ confidence intervals of the estimated parameters

${ }^{\mathrm{c}}$ Standard error of estimate

${ }^{\mathrm{d}}$ All coefficients of determination were significant at a $P \leq 0.01$ 
Table 4.

Sorption - $\mathrm{pH}$ functional relationships $(\operatorname{Ln} S=m p H+b)$

\begin{tabular}{|c|c|c|c|c|c|c|c|c|}
\hline Metal sol. & Soil No & $\mathrm{pH}_{\text {range }}{ }^{\mathrm{a}}$ & $m$ & $\mathrm{CI}^{\mathrm{b}}$ & $b$ & $\mathrm{CI}$ & $\mathrm{SE}^{\mathrm{c}}$ & $R^{2 \mathrm{~d}}$ \\
\hline \multirow[t]{4}{*}{$\mathrm{Pb}$} & $\mathrm{S} 1$ & $4.5-3.7$ & -2.83 & 0.51 & 11.63 & 2.09 & 0.124 & 0.82 \\
\hline & $\mathrm{S} 2$ & $4.1-3.7$ & -7.92 & 2.39 & 32.57 & 9.50 & 0.302 & 0.97 \\
\hline & S3 & $4.6-3.7$ & -3.40 & 1.13 & 14.56 & 4.62 & 0.296 & 0.83 \\
\hline & $\mathrm{S} 4$ & $4.1-3.6$ & -4.49 & 1.11 & 19.62 & 4.26 & 0.150 & 0.98 \\
\hline \multirow[t]{4}{*}{$\mathrm{Cd}$} & $\mathrm{S} 1$ & $4.1-3.7$ & -6.17 & 1.64 & 25.59 & 6.38 & 0.196 & 0.99 \\
\hline & $\mathrm{S} 2$ & $4.2-4.1$ & -27.38 & 9.31 & 115.64 & 38.41 & 0.236 & 0.96 \\
\hline & $\mathrm{S} 3$ & $4.0-3.6$ & -6.23 & 2.06 & 25.67 & 7.84 & 0.220 & 0.98 \\
\hline & $\mathrm{S} 4$ & $4.0-3.9$ & -11.62 & 2.91 & 49.24 & 11.60 & 0.072 & 0.99 \\
\hline \multirow[t]{4}{*}{$\mathrm{Pb}(+\mathrm{Cd})$} & $\mathrm{S} 1$ & $4.0-3.5$ & -6.62 & 1.61 & 25.99 & 6.09 & 0.213 & 0.90 \\
\hline & $\mathrm{S} 2$ & $4.3-3.6$ & -3.89 & 1.07 & 16.27 & 4.24 & 0.283 & 0.98 \\
\hline & $\mathrm{S} 3$ & $3.9-3.5$ & -7.56 & 2.13 & 30.03 & 7.99 & 0.287 & 0.98 \\
\hline & S4 & $3.9-3.5$ & -4.26 & 0.65 & 17.96 & 2.41 & 0.090 & 0.99 \\
\hline \multirow[t]{4}{*}{$\mathrm{Cd}(+\mathrm{Pb})$} & $\mathrm{S} 1$ & $4.0-3.5$ & -5.98 & 0.88 & 24.63 & 3.32 & 0.116 & 0.98 \\
\hline & $\mathrm{S} 2$ & $4.3-3.6$ & -3.36 & 1.20 & 15.56 & 4.75 & 0.266 & 0.96 \\
\hline & S3 & $3.9-3.5$ & -4.93 & 0.54 & 20.85 & 2.03 & 0.073 & 0.99 \\
\hline & $\mathrm{S} 4$ & $3.9-3.5$ & -3.10 & 0.74 & 14.32 & 2.76 & 0.102 & 0.97 \\
\hline
\end{tabular}

${ }^{\mathrm{a}} \mathrm{pH}$ ranges of the equilibrated solutions from the lowest and highest metal initial concentrations

${ }^{\mathrm{b}} \mathrm{CI}, 95 \%$ confidence intervals of the estimated parameters

${ }^{\mathrm{c}}$ Standard error of estimate

${ }^{\mathrm{d}}$ All coefficients of determination were significant at a $P \leq 0.01$ 
Table 5 .

Apparent sorption rate coefficients for different initial concentrations $\left(S=k t^{\nu}\right)$

\begin{tabular}{|c|c|c|c|c|c|c|c|c|c|c|c|c|c|c|c|c|c|}
\hline & \multirow[b]{2}{*}{$\mathrm{C}_{\mathrm{o}}{ }^{\mathrm{a}}$} & \multicolumn{4}{|c|}{$\mathrm{S} 1$} & \multicolumn{4}{|c|}{ S2 } & \multicolumn{4}{|c|}{ S3 } & \multicolumn{4}{|c|}{ S4 } \\
\hline & & $v$ & $\mathrm{CI}^{\mathrm{b}}$ & $\mathrm{SE}^{\mathrm{c}}$ & $R^{2 \mathrm{~d}}$ & $v$ & $\mathrm{CI}$ & SE & $R^{2}$ & $v$ & $\mathrm{CI}$ & SE & $R^{2}$ & $v$ & $\mathrm{CI}$ & SE & $R^{2}$ \\
\hline \multirow[t]{4}{*}{$\mathrm{Pb}$} & 1 & 0.001 & 0.000 & 0.10 & 0.97 & 0.002 & 0.000 & 8.20 & 0.93 & 0.004 & 0.001 & 0.59 & 0.95 & 0.0005 & 0.000 & 2.10 & 0.94 \\
\hline & 2 & 0.001 & 0.000 & 0.30 & 0.98 & 0.005 & 0.001 & 18.96 & 0.97 & 0.006 & 0.001 & 1.18 & 0.98 & 0.0007 & 0.000 & 3.63 & 0.96 \\
\hline & 3 & 0.005 & 0.001 & 2.58 & 0.98 & 0.013 & 0.003 & 91.18 & 0.94 & 0.020 & 0.004 & 14.30 & 0.95 & 0.0023 & 0.000 & 8.06 & 0.98 \\
\hline & 4 & 0.019 & 0.002 & 13.81 & 0.99 & 0.033 & 0.005 & 184.33 & 0.98 & 0.051 & 0.005 & 28.58 & 0.99 & 0.0028 & 0.000 & 20.63 & 0.98 \\
\hline \multirow[t]{4}{*}{$\mathrm{Cd}$} & 1 & 0.023 & 0.003 & 2.43 & 0.97 & 0.016 & 0.003 & 44.20 & 0.95 & 0.034 & 0.005 & 2.60 & 0.97 & 0.0013 & 0.000 & 1.68 & 0.99 \\
\hline & 2 & 0.036 & 0.003 & 2.82 & 0.99 & 0.022 & 0.003 & 48.36 & 0.98 & 0.035 & 0.005 & 4.42 & 0.97 & 0.0014 & 0.000 & 3.18 & 0.98 \\
\hline & 3 & 0.042 & 0.004 & 10.12 & 0.98 & 0.030 & 0.005 & 91.62 & 0.97 & 0.035 & 0.006 & 8.33 & 0.97 & 0.0022 & 0.000 & 9.14 & 0.97 \\
\hline & 4 & 0.055 & 0.008 & 30.60 & 0.98 & 0.057 & 0.006 & 126.82 & 0.99 & 0.031 & 0.006 & 14.81 & 0.96 & 0.0074 & 0.001 & 40.22 & 0.98 \\
\hline \multirow[t]{4}{*}{$\mathrm{Pb}(+\mathrm{Cd})$} & 1 & 0.001 & 0.000 & 0.16 & 0.89 & 0.001 & 0.000 & 2.36 & 0.97 & 0.003 & 0.000 & 0.18 & 0.98 & 0.0003 & 0.000 & 1.04 & 0.91 \\
\hline & 2 & 0.003 & 0.001 & 0.70 & 0.95 & 0.004 & 0.001 & 11.90 & 0.96 & 0.006 & 0.001 & 0.68 & 0.98 & 0.0007 & 0.000 & 2.46 & 0.94 \\
\hline & 3 & 0.004 & 0.000 & 1.21 & 0.98 & 0.006 & 0.001 & 28.55 & 0.94 & 0.020 & 0.002 & 5.71 & 0.98 & 0.0011 & 0.000 & 4.71 & 0.96 \\
\hline & 4 & 0.009 & 0.001 & 5.27 & 0.98 & 0.029 & 0.006 & 177.35 & 0.95 & 0.039 & 0.006 & 25.38 & 0.97 & 0.0030 & 0.001 & 23.93 & 0.93 \\
\hline \multirow[t]{4}{*}{$\mathrm{Cd}(+\mathrm{Pb})$} & 1 & 0.023 & 0.003 & 0.76 & 0.98 & 0.020 & 0.003 & 17.55 & 0.97 & 0.040 & 0.005 & 0.71 & 0.98 & 0.0011 & 0.000 & 2.92 & 0.84 \\
\hline & 2 & 0.031 & 0.001 & 0.53 & 1.00 & 0.038 & 0.005 & 35.38 & 0.98 & 0.052 & 0.007 & 2.28 & 0.98 & 0.0019 & 0.001 & 5.86 & 0.87 \\
\hline & 3 & 0.059 & 0.009 & 7.85 & 0.97 & 0.050 & 0.010 & 74.35 & 0.96 & 0.054 & 0.009 & 5.43 & 0.97 & 0.0056 & 0.002 & 22.30 & 0.88 \\
\hline & 4 & 0.063 & 0.008 & 9.19 & 0.98 & 0.054 & 0.010 & 85.24 & 0.96 & 0.054 & 0.007 & 6.30 & 0.98 & 0.0071 & 0.002 & 37.65 & 0.88 \\
\hline
\end{tabular}

${ }^{\mathrm{a}}$ Increasing initial concentration solutions used for kinetic experiments as shown in table 1 .

${ }^{\mathrm{b}} \mathrm{CI}, 95 \%$ confidence intervals of the estimated parameters

${ }^{c}$ Standard error of estimate

${ }^{\mathrm{d}}$ All coefficients of determination were significant a $P \leq 0.01$ 
2 Table 6

Q parameter - equilibrium time functional relationships $\left(Q=a t^{b}\right)$ 4

\begin{tabular}{|c|c|c|c|c|c|c|c|}
\hline Soil & Metal Sol. & $\mathrm{a}$ & $\mathrm{CI}^{\mathrm{a}}$ & $\mathrm{b}$ & $\mathrm{CI}$ & $\mathrm{SE}^{\mathrm{b}}$ & $\mathrm{R}^{2 \mathrm{c}}$ \\
\hline \multirow[t]{4}{*}{$\mathrm{S} 1$} & $\mathrm{~Pb}$ & 2517 & 31.16 & 0.0180 & 0.0026 & 28.36 & 0.98 \\
\hline & $\mathrm{Cd}$ & 1506 & 104.36 & 0.0578 & 0.0135 & 94.82 & 0.94 \\
\hline & $\mathrm{Pb}(+\mathrm{Cd})$ & 2380 & 146.14 & 0.0324 & 0.0073 & 126.36 & 0.94 \\
\hline & $\mathrm{Cd}(+\mathrm{Pb})$ & 626 & 14.66 & 0.0364 & 0.0047 & 12.77 & 0.98 \\
\hline \multirow[t]{4}{*}{$\mathrm{S} 2$} & $\mathrm{~Pb}$ & 10305 & 80.88 & 0.0304 & 0.0016 & 69.68 & 1.00 \\
\hline & $\mathrm{Cd}$ & 5567 & 169.77 & 0.0455 & 0.0060 & 150.53 & 0.98 \\
\hline & $\mathrm{Pb}(+\mathrm{Cd})$ & 7832 & 189.63 & 0.0335 & 0.0049 & 164.31 & 0.97 \\
\hline & $\mathrm{Cd}(+\mathrm{Pb})$ & 2183 & 124.44 & 0.0634 & 0.0110 & 114.38 & 0.97 \\
\hline \multirow[t]{4}{*}{$\mathrm{S} 3$} & $\mathrm{~Pb}$ & 1600 & 68.73 & 0.0491 & 0.0085 & 61.37 & 0.96 \\
\hline & $\mathrm{Cd}$ & 1144 & 6.54 & 0.0241 & 0.0012 & 5.47 & 0.99 \\
\hline & $\mathrm{Pb}(+\mathrm{Cd})$ & 2114 & 75.11 & 0.0393 & 0.0071 & 65.80 & 0.96 \\
\hline & $\mathrm{Cd}(+\mathrm{Pb})$ & 796 & 67.52 & 0.0220 & 0.0154 & 69.00 & 0.98 \\
\hline \multirow[t]{4}{*}{ S4 } & $\mathrm{Pb}$ & 23916 & 203.35 & 0.0084 & 0.0018 & 168.37 & 0.95 \\
\hline & $\mathrm{Cd}$ & 15387 & 127.38 & 0.0120 & 0.0017 & 106.14 & 0.97 \\
\hline & $\mathrm{Pb}(+\mathrm{Cd})$ & 14413 & 191.61 & 0.0069 & 0.0028 & 158.23 & 0.83 \\
\hline & $\mathrm{Cd}(+\mathrm{Pb})$ & 6909 & 73.62 & 0.0084 & 0.0022 & 60.96 & 0.92 \\
\hline
\end{tabular}

${ }^{a} \mathrm{CI}, 95 \%$ confidence intervals of the estimated parameters

${ }^{\mathrm{b}}$ Standard error of estimate

${ }^{\mathrm{c}}$ All coefficients of determination were significant at a $P \leq 0.01$

8

9

10 
1

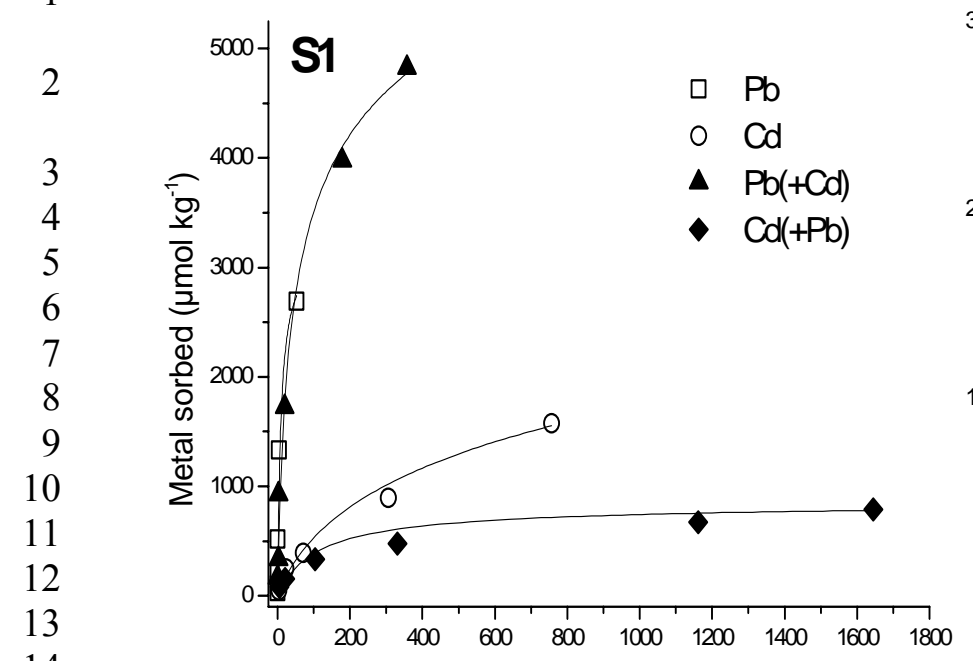

14

15

16

17

18

19

20

21

22

23

24

25

26

27

28

29

30 Figure 1

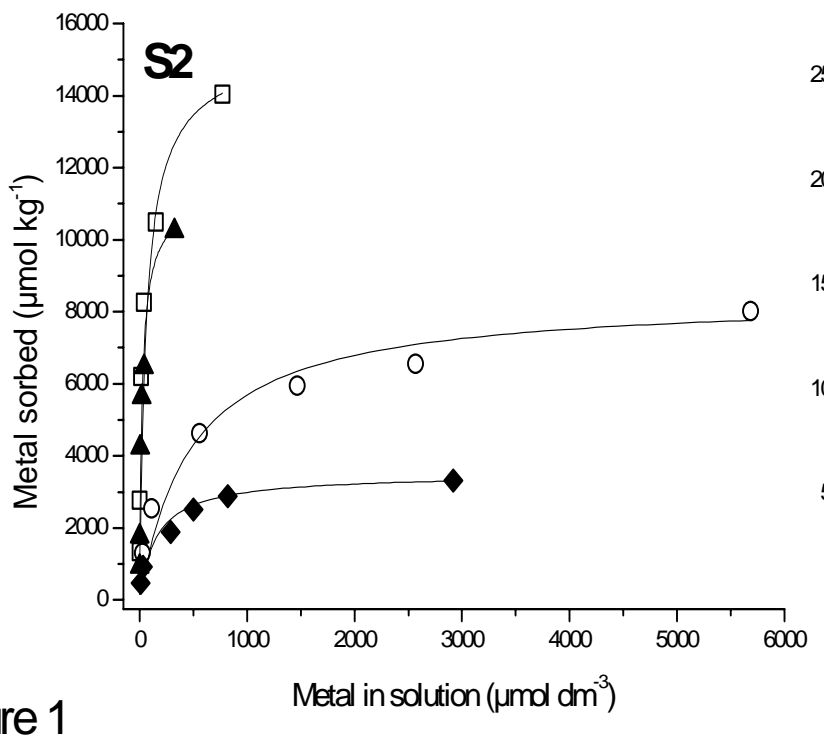

31

32

33
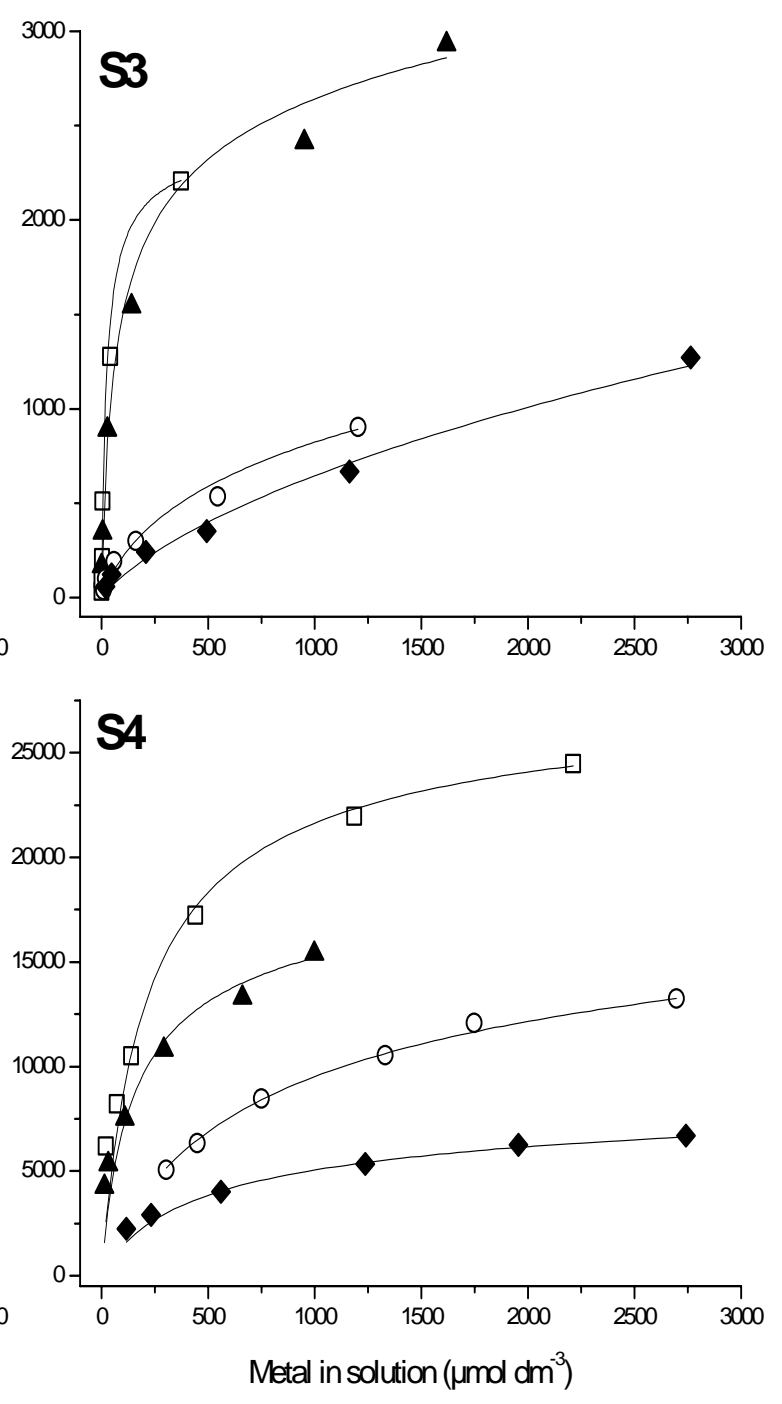
1

2

3
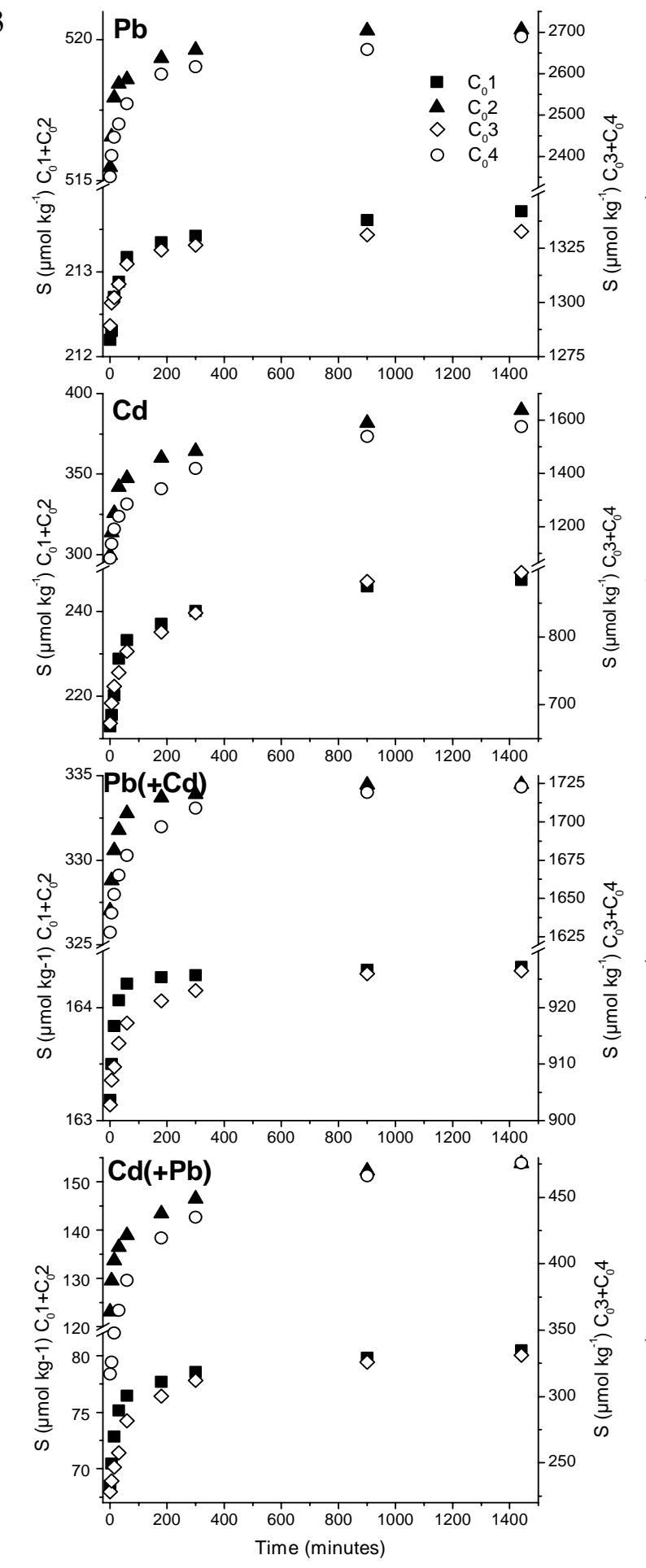

S2
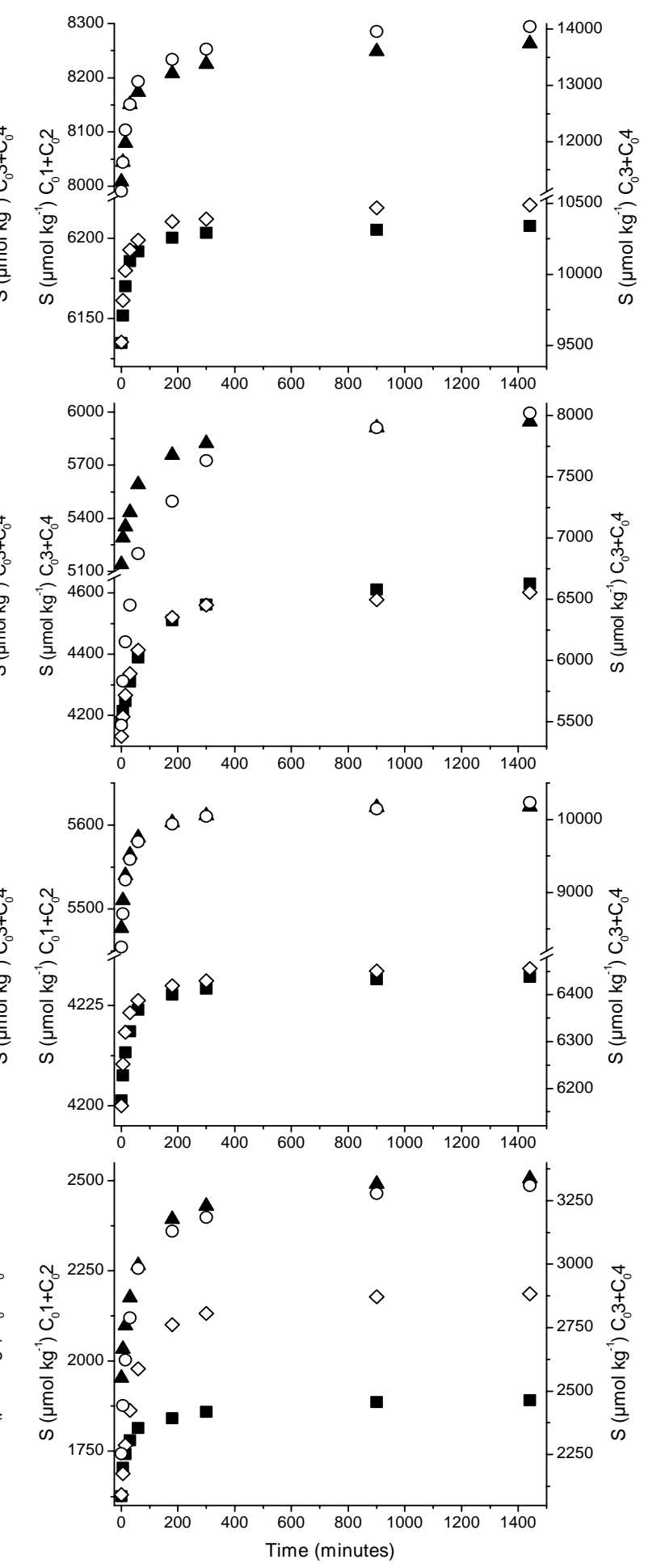

Figure 2 